\title{
PERAN KECERDASAN INTELEKTUAL DAN SELF REGULATED LEARNING TERHADAP PRESTASI BELAJAR MAHASISWA
}

\author{
Usman Hidayat \\ Fakultas Psikologi UIN Sunan Gunung Djati Bandung, Jl. A.H Nasution No. 105 Bandung \\ email: usman_antikemapanan@yahoo.com
}

\begin{abstract}
Abstrak
Penelitian ini secara khusus menyelidiki faktor-faktor personal dari mahasiswa, baik bersifat demografis ataupun psikologis yang diduga berpengaruh terhadap prestasi belajar yang dimilikinya. Faktor demografis yang akan diteliti adalah kecerdasan intelektual dan faktor psikologis yang akan diteliti adalah keteraturan diri dalam belajar (self regulated learning). Konsep keteraturan diri dalam belajar (self regulated learning) bersumber dari konsep self regulation yang dikemukakan oleh Bandura (1997), namun sudah dimodifikasi dan dispesialisasi untuk ranah pendidikan oleh Zimmerman (2000). Rancangan penelitian ini menerapkan rancangan korelasional, multiple regression. Data penelitian, meliputi: (1) Data primer, yakni data-data yang berhubungan dengan keteraturan diri dalam belajar (self regulated learning), dan (2) Data sekunder, yakni datadata yang berhubungan dengan taraf kecerdasan dan hasil prestasi belajar yang berupa nilai IPK. Data sekunder diperoleh dari hasil psikotes yang diselengarakan oleh laboratorium Fakultas Psikologi UIN SGD Bandung dan data yang terdapat di Fakultas Psikologi UIN SGD Bandung. Hasil analisis data menunjukkan bahwa koefisien korelasi ketiga variabel independen dengan variabel dependen sebesar 0.564 dengan nilai $\mathrm{R}^{2}$ sebesar 0.310. Hal tersebut menunjukkan bahwa variasi pada prestasi belajar 31 persennya ditentukan oleh kecerdasan intelektual dan keteraturan diri dalam belajar (self regulated learning). Sementara itu, 69 persennya lagi ditentukan oleh variabel lain.
\end{abstract}

Kata kunci: kecerdasan intelektual, keteraturan diri dalam belajar, dan prestasi belajar

\section{Abstract}

This research specifically observes the personal factors of students, both demographically and psychologically expected to influence to achievement of study had by them. Demographic factor that will be observed is intellectual quotient and psychological factor that will be observed is self regulated learning. Self regulated learning comes from the concept of self regulation which is said by Bandura (1997), but it has been modified and specified for education domain by Zimmerman (2000). This research plan applies correlation plan, multiple regression. The research data include: (1) primer data, i.e., data correlating to self regulated learning, and (2) secondary data, i.e., the data correlating to the standard of quotient and the result of study achievement (IPK). The secondary data is gotten from the result of psycho test implemented by the laboratory of Sunan Gunung Djati Bandung State Islamic University psychology faculty and the data existing in Sunan Gunung Djati Bandung State Islamic University Psychology Faculty. The result of analysis data shows that the correlation coefficient of all three independent variables with dependent variable $=0.564$ and $R^{2}=0.310$. It shows that 31 percent of study achievement variety is determined by intellectual quotient and self regulated learning. Furthermore, 69 percent of it is determined by the other variables.

Keywords: intellectual quotient, self regulated learning and study achievement 


\section{PENDAHULUAN}

Masalah pendidikan merupakan salah satu faktor penting dalam pembangunan manusia seutuhnya, karena kemampuan, kecerdasan, dan kepribadian suatu bangsa yang akan datang ditentukan oleh pendidikan yang ada sekarang, bahkan kemajuan suatu bangsa banyak ditentukan oleh keberhasilan dalam bidang pendidikannya (Nasir, 1999: 17).

Indonesia sebagai negara yang sedang berkembang, terus menerus mengupayakan kemajuan pendidikan dan berbagai dimensi lain, baik fisik maupun spiritual. Meskipun demikian, kualitas pendidikan di Indonesia belum memperlihatkan hasil yang maksimal yang dapat dirasakan secara merata oleh seluruh masyarakat Indonesia. Data yang dilaporkan The World Economic Forum Swedia (2000), dalam bidang pendidikan Indonesia memiliki daya saing yang rendah, yaitu hanya menduduki urutan ke- 37 dari 57 negara yang disurvei di dunia. Masih menurut survey dari lembaga yang sama, Indonesia hanya berpredikat sebagai follower bukan sebagai pemimpin teknologi dari 53 negara di dunia. Kualitas pendidikan Indonesia yang rendah itu juga ditunjukkan data Balitbang (2003) bahwa dari 146.052 SD di Indonesia ternyata hanya delapan sekolah saja yang mendapat pengakuan dunia dalam kategori The Primary Years Program (PYP). Dari 20.918 SMP di Indonesia ternyata juga hanya delapan sekolah yang mendapat pengakuan dunia dalam kategori The Middle Years Program (MYP) dan dari 8.036 SMA ternyata hanya tujuh sekolah saja yang mendapat pengakuan dunia dalam kategori The Diploma Program.

Menurut Suseno (2006) rendahnya kualitas pendidikan di Indonesia dapat dikategorikan dalam 2 (dua) permasalahan yaitu :

Pertama, masalah mendasar, yaitu kekeliruan paradigma pendidikan yang mendasari keseluruhan penyelenggaraan sistem pendidikan. Kedua, masalah-masalah cabang, yaitu berbagai problem yang berkaitan aspek praktis/teknis yang berkaitan dengan penyelenggaraan pendidikan, seperti rendahnya kualitas sarana fisik, rendahnya kualitas tenaga pengajar, rendahnya kesejahteraan tenaga pengajar, rendahnya prestasi siswa, kurangnya pemerataan kesempatan pendidikan, rendahnya relevansi pendidikan dengan kebutuhan (adanya ketidakserasian antara hasil pendidikan dan kebutuhan dunia kerja ini disebabkan kurikulum yang materinya kurang fungsional terhadap keterampilan yang dibutuhkan ketika peserta didik memasuki dunia kerja), mahalnya biaya pendidikan dan sebagainya.

Permasalahan yang tercakup dalam aspek praktis/teknis yang berkaitan dengan penyelenggaraan pendidikan khususnya di Perguruan Tinggi. Proses belajar di Perguruan Tinggi sangat berbeda dengan belajar di tingkat pendidikan sebelumnya. Mahasiswa harus mengikuti kuliah secara tertib, mempelajari bukubuku yang pada umumnya tertulis dalam bahasa asing, harus menghafalkan berbagai macam teori dan pengertian, harus melakukan penelitian di laboratorium atau perpustakaan. Tanggung jawab belajar hampir seluruhnya dipercayakan pada mahasiswa itu sendiri. Pengajar atau dosen hanya memberikan dasar-dasar pengetahuan saja, sehingga para mahasiswa harus betul-betul mencurahkan pikiran dan tenaganya untuk belajar. Hal seperti ini pula berlaku di Fakultas Psikologi UIN Sunan Gunung Djati Bandung bahwa mahasiswanya harus beradaptasi dengan proses belajar mengajar yang tentunya baru dan berbeda dengan yang diperoleh selama di jenjang pendidikan sebelumnya.

Pada Fakultas Psikologi dari semester satu sampai semester tiga, proses belajar dilakukan dengan mengikuti perkuliahan tatap muka di dalam kelas. Pada semester empat mata kuliah praktikum mulai diberikan. Mata kuliah prak-tikum yang ada di Fakultas Psikologi memuat mata kuliah psikodiagnostik, pada mata kuliah tersebut mahasiswa harus mengikuti perkuliahan dari mulai psikodiagnostika I sampai psikodiagnostika VIII. Mata kuliah psikodiagnostik sering dianggap mata kuliah yang memiliki tingkat kesulitan yang lebih tinggi daripada mata kuliah lainnya. Pada mata kuliah praktikum mahasiswa melakukan berbagai aktivitas seperti: berlatih dan berperan menjadi seorang tester ataupun observer (role play), mempraktekkan hasil role play terhadap subjek yang penelitian, kegiatan feedback terhadap hasil role play maupun hasil pengambilan data (responsi), dan melakukan skoring/ penilaian terhadap hasil pengambilan data.

Proses belajar yang dilakukan seorang mahasiswa akan berbeda dengan mahasiswa lainnya sehingga prestasi belajar seorang mahasiswa pun akan berbeda dengan prestasi belajar mahasiswa lainnya. 
Evaluasi diri yang pernah dilakukan oleh pihak Fakultas Psikologi UIN Sunan Gunung Djati Bandung menunjukkan bahwa program studi psikologi masih dihadapkan pada banyak masalah yang berkenaan dengan keberhasilan studi mahasiswa. Data yang diperoleh menunjukkan bahwa mahasiswa psikologi relatif lama di dalam menyelesaikan studinya (10 sd 14 semester). Selain itu, rata-rata IPK mahasiswa pun termasuk rendah (rata-rata 2,52). Permasalahan lain yang muncul adalah tingginya tingkat putus studi mahasiswa, baik karena drop out (DO), cuti, ataupun keluar tanpa pemberitahuan. Berbagai hal tersebut salah satunya menunjukkan tingkat prestasi belajar yang kurang memuaskan dari mahasiswa Fakultas Psikologi UIN Sunan Gunung Djati Bandung.

Penelitian ini secara khusus menyelidiki faktor-faktor personal dari mahasiswa, baik yang bersifat demografis ataupun psikologis yang diduga berpengaruh terhadap prestasi belajar yang dimilikinya. Faktor demografis yang akan diteliti adalah kecerdasan intelektual. Faktor ini diteliti karena diduga berpengaruh terhadap prestasi belajar mahasiswa. Hal tersebut didukung oleh penelitian Hikmawati, dkk (2009) yang menunjukkan bahwa kecerdasan intelektual memiliki pengaruh yang cukup signifikan terhadap prestasi belajar. Hal tersebut terjadi karena menurutnya kecerdasan intelektual berpengaruh terhadap kecepatan dan efektivitas penerimaan, pengolahan, penilaian, serta penyimpanan bahan ajar. Fakta yang diperoleh dari Laboratorium Psikologi UIN Sunan Gunung Djati Bandung dari hasil psikotes terhadap mahasiswa angkatan 2007-2008 diketahui bahwa sebaran tingkat IQ mahasiswa yang sangat beragam, yaitu berkisar antara 78 sampai 120.

Menurut Wechsler (1944: 3) intelegensi adalah suatu agregat atau kapasitas global dari individu untuk dapat bertindak secara rasional dan berhubungan secara efektif dengan lingkungannya. Menurut Hikmawati, dkk (2009) Kecerdasan intelektual berpengaruh terhadap kemampuan mahasiswa dalam menerima, mengolah, menilai serta menyimpan bahan ajar. Mahasiswa yang mempunyai taraf kecerdasan yang rendah akan mengalami kesulitan di dalam menangkap, memahami, dan menyimpan informasi yang disampaikan oleh dosennya. Bukan hanya itu, ia pun diduga akan kesulitan di dalam menganalisis, membayangkan, dan melakukan penilaian secara logis dan akurat. Kenyataannya, dalam proses belajar mengajar di perguruan tinggi sering ditemukan mahasiswa yang tidak memperoleh prestasi belajar yang setara dengan kemampuan intelegensinya. Ada mahasiswa yang mempunyai kemampuan intelegensi tinggi tetapi memperoleh prestasi belajar yang relatif rendah, namun ada mahasiswa yang walaupun kemampuan intelegensinya relatif rendah, dapat meraih prestasi belajar yang relatif tinggi. Itu sebabnya taraf intelegensi bukan merupakan satu-satunya faktor yang menentukan keberhasilan seseorang, karena ada faktor lain yang mempengaruhi.

Adapun, faktor psikologis yang akan diteliti adalah keteraturan diri dalam belajar (self regulated learning). Konsep keteraturan diri dalam belajar (self regulated learning) bersumber dari konsep self regulation yang dikemukakan oleh Bandura (1997), namun sudah dimodifikasi dan dispesialisasi untuk ranah pendidikan.

Menurut Zimmerman (2000, dalam Schunk, 2001:1) keteraturan diri dalam belajar (self regulated learning) adalah usaha yang sistematis untuk mengarahkan pikiran, perasaan dan tindakan untuk mencapai tujuan yang dimiliki. Kemudian, hal tersebut diantaranya dapat dilihat dari adanya usaha melakukan manajemen waktu (time management), menetapkan tujuan belajar (goal setting), menggunakan fasilitas atau jasa tertentu untuk membantu agar aktivitas belajar lebih efektif (help seeking), misalnya dengan memilih model belajar tertentu, memilih guru khusus, atau buku yang dapat membantu dalam proses belajar, serta adanya self efficacy yang tinggi (Zimmerman \& Kitsantas, 2005:510-511).

Berdasarkan hasil interview dengan beberapa mahasiswa yang memiliki nilai IPK di atas 3,00 diperoleh informasi bahwa mereka mendapatkan prestasi tersebut bukan hanya mengandalkan kemampuan intelegensi saja, tetapi mereka juga sudah memiliki tujuan yang jelas dalam belajar serta mampu meluangkan waktu untuk mempelajari sendiri materi perkuliahan yang telah diberikan di kelas. Usahausaha yang dilakukan oleh mahasiswa, yang terindikasi sudah mempunyai kejelasan berkaitan dengan orientasi pendidikan seperti yang telah dipaparkan sebelumnya, menurut konsep psikologi pendidikan merupakan indikasi dari adanya keteraturan diri dalam belajar (Self Regulated Learning). 
Berdasarkan fakta-fakta hasil wawancara dan data dari pihak Fakultas Psikologi UIN Sunan Gunung Djati Bandung yang telah dipaparkan pada bagian latar belakang, memunculkan ketertarikan pada diri peneliti untuk melakukan penelitian yang berjudul "Peran kecerdasan intelektual dan keteraturan diri dalam belajar (self regulated learning) terhadap prestasi belajar mahasiswa Fakultas Psikologi UIN Sunan Gunung Djati Bandung”.

Kecerdasan intelektual atau lebih dikenal dengan istilah intelegensi berasal dari hasil kerja Alfred Binet (1857 - 1911). Intelegensi merupakan istilah yang menggambarkan kecerdasan dan kemampuan untuk memecahkan persoalan yang dihadapi merupakan istilah yang sering dikaitkan dengan kemampuan seseorang dalam konteks akademis. Selama bertahun-tahun dunia akademik, dunia militer (sistem rekrutmen dan promosi personel militer) dan dunia kerja, menggunakan IQ sebagai standar mengukur kecerdasan seseorang.

Menurut Wechsler (1944: 3) intelegensi adalah suatu agregat atau kapasitas global dari individu untuk dapat berfikir secara rasional, bertindak terarah dan berhubungan secara efektif dengan lingkungannya. Dari definisi tersebut peneliti mendapatkan dua istilah pokok dalam pengertian intelegensi yaitu: kappasitas global yang berarti kapasitas keseluruhan dari cici-ciri atau karakter individu, dan agregat yang berarti intelegensi merupakan elemen-elemen yang dimiliki individu berupa kemampuan, berfikir, dan memori yang semuanya itu tidak terpisah satu sama lain. Menurutnya pengertian intelegensi merupakan jumlah dari kemampuan-kemampuan individu namun bukan berarti diantara kemampuan tersebut saling terpisah atau berdiri sendiri. Karena intelegensi merupakan cara kerja yang terkombinasi diantara kemampuan-kemampuan individu, ada faktor lain yang memengaruhi intelegensi yaitu dorongan dan insentif, dan intelegensi merupakan suatu aktivitas yang memberikan beberapa kemampuan untuk keefektifan tingkah laku.

Spearman (dalam Suryabrata 1995: 128) menemukan bahwa tiap tingkah laku manusia dimungkinkan atau disebabkan oleh dua faktor yaitu faktor umum (general faktor) dan faktor khusus (special faktor).

Faktor umum (general faktor) itu, yang dilambangkan dengan huruf " $g$ " merupakan hal yang mendasari seluruh tingkah laku indi- vidu. Sedangkan faktor khusus atau special faktor yang dilambangkan dengan " $s$ " adalah intelegensi yang hanya berfungsi pada tingkah laku khusus saja. Jadi dengan demikian setiap tingkah laku dimungkinkan adanya faktor " $g$ " dan faktor " $s$ ", faktor " $g$ " berfungsi pada setiap tingkah laku. Jadi yang berfungsi pada tingkah laku-tingkah laku yang berbeda adalah faktor " $g$ " yang sama dan faktor " $s$ " yang tidak sama.

Sebagian ahli psikologi memandang intelegensi sebagai kapasitas umum untuk memahami dan menalar sesuatu yang bermanifestasi dalam banyak cara. Inilah yang diasumsikan oleh Binet (dalam Suryabrata 1995: 137). Binet menyatakan bahwa anak yang cerdas cenderung memiliki nilai yang lebih tinggi dibandingkan dengan anak yang bodoh. Oleh karena itu ia berpendapat bahwa tugas yang berbeda menggali kecakapan atau kemampuan dasar.

Menurut Binet (dalam Ngaliman, 1990) dalam intelegensi terdapat kecakapan dasar, yang bila mengalami perubahan atau kekurangan akan memengaruhi kehidupan praktis. Kecakapan ini berupa daya timbang, yang disebut juga akal sehat, akal praktis, inisiatif, kecakapan adaptasi dengan situasi.

Keteraturan diri dalam belajar didefinisikan oleh Zimmerman, Schunk \& Ertmer (dalam Ruohotie, 2002:37) sebagai "Self generated thoughts, feelings, and actions that are planned and systematically adapted as needed to affect one 's learning". Dari definisi tersebut dapat dikemukakan bahwa keteraturan diri dalam belajar (self regulated learning) adalah pengarahan diri yang mencakup pikiran, perasaan dan tindakan yang direncanakan dan diadaptasi secara sistematis sebagai kebutuhan untuk memengaruhi cara belajar seseorang.

Menurut Zimmerman (1989:2-7) keteraturan diri dalam belajar (self regulated learning) dipengaruhi oleh tiga faktor, yaitu individu yang bersangkutan (person), faktor tingkah laku (behavior), dan faktor lingkungan (environment). Kemudian ketiga faktor tersebut bersifat interaktif dan dinamakan sebagai Triadic Form of Self Regulation (Zimmerman, 2000:15, dalam Ruohotie, 2002:38) yang terdiri dari:

Faktor personal. Faktor personal yang berpengaruh penting terhadap keteraturan diri dalam belajar (self regulated learning) adalah persepsi siswa akan kemampuan dirinya (self 
efficacy). Karena, self efficacy berkaitan erat dengan pemilihan strategi yang ia gunakan dalam belajar dan pengawasan diri (self monitoring). Kemudian, berdasarkan penelitian menunjukan, bahwa self efficacy siswa berhubungan secara positif dengan hasil belajar (learning outcomes), seperti: ketepatan tugas (task persistance), pilihan tugas (task choice), aktivitas belajar yang efektif (effective study activities), pemerolehan keterampilan (skill acquisition) dan prestasi akademik (academic achievement).

Faktor tingkah laku. Terdiri dari berbagai proses performa yang bersifat aplikatif (applicable performance processes) seperti:

Pengamatan diri (self observation), yaitu respon-respon siswa yang meliputi pengawasan sistematis terhadap penampilan mereka sendiri. Pengawasan tersebut berfungsi untuk menyediakan informasi tentang bagaimana atau seberapa baik penampilan mereka menunjang terhadap terwujudnya tujuan yang dimiliki.

Penilaian diri (Self judgment) adalah responrespon siswa yang meliputi pembandingan secara sistematis antara penampilan mereka dengan suatu standar atau tujuan yang telah ditetapkan. Standar atau tujuan tersebut dapat berupa norma-norma sosial, kriteria sementara atau kriteria absolut yang telah ditetapkan.

Reaksi diri (self reaction) adalah tanggapan atau pemaknaan siswa terhadap evaluasi atas penampilan yang ditunjukannya. Berdasarkan social cognitive theory, reaksi diri (self reaction) dibedakan atas tiga bentuk: (a) behavioral self reaction, yaitu siswa berusaha untuk mengoptimalkan respon-respon spesifik mereka ketika belajar; (b) personal self reaction, yaitu siswa berusaha untuk meningkatkan proses diri mereka ketika belajar, misalnya dengan melakukan proses pengulangan (rehearsing); (c) environmental self reaction, yaitu siswa berusaha memperbaiki atau membenahi lingkungan belajar mereka, seperti menciptakan lingkungan yang kondusif untuk belajar, atau meminta bantuan kepada orang lain.

Faktor lingkungan. Mencakup aktivitas mengamati dan penyesuaian kondisi lingkungan serta akibat-akibat atau hasil (Zimmerman 2000, dalam Ruohotie, 2002:38). Faktor ini dipengaruhi oleh hal-hal berikut ini:

Pemodelan (modeling), yaitu berperan dalam meningkatkan self efficacy. Secara teori, model akan berperan secara efektif apabila model dipersepsi sesuai dengan dirinya oleh pengamat.
Bujukan verbal (verbal persuasion), yaitu bujukan verbal untuk memengaruhi strategi pengaturan diri yang dilakukan oleh siswa (self regulation strategies), dan efektivitas hal ini tergantung pada tingkat pemahaman siswa terhadap bujukan verbal yang disampaikan. Kemudian, cara ini akan menjadi sangat berguna apabila dikombinasikan dengan pemodelan (modeling).

Dua hal di atas, yaitu pemodelan dan bujukan verbal, merupakan dukungan yang berperan dalam membantu siswa dalam aktivitas belajarnya, tetapi di samping itu menurut Zimmerman \& Martinez-Pons (1986) ada juga dukungan sosial lain yang berupa: (1) bantuan langsung dari guru, siswa yang lain, atau orang yang lebih dewasa lainnya; dan (2) literatur atau informasi dalam bentuk-bentuk simbolik seperti diagram, gambar, atau rumus-rumus.

Struktur konteks belajar (structure of the learning context) khususnya seperti elemenelemen tugas akademik dan seting akademik. Berdasarkan teori sosial kognitif, aktivitas belajar manusia tergantung pada konteks lingkungannya, seperti tingkat kesulitan tugas dan suasana lingkungan belajarnya.

Prestasi belajar sangat erat kaitannya dengan proses belajar. Gage \& Berliner (1979 : 256) mengungkapkan prestasi belajar sebagai : “........ is something acquired or learned, results from an active learning process helped along by instruction and education activity." Dengan kata lain, prestasi merupakan sesuatu yang dicapai atau hasil dari sesuatu yang dipelajari, dimana hal ini merupakan hasil dari proses belajar yang dibantu oleh instruksi dan kegiatan pendidikan.

Menurut Winkel (1989), proses belajar mengajar menghasilkan perubahan-perubahan di pihak siswa, dimana perubahan-perubahan itu merupakan kemampuan di berbagai bidang yang sebelumnya tidak dimiliki. Kemampuankemampuan itu dihasilkan karena usaha belajar, namun masih merupakan kemampuan internal yang harus dinyatakan atau dibuktikan dalam suatu prestasi. Prestasi belajar yang diberikan oleh siswa berdasarkan kemampuan internal yang diperolehnya sesuai dengan tujuan instruksional, yang menampakkan hasil belajar. Dari tepat atau tidak tepatnya prestasi belajar akan nampak, apakah hasil belajar telah tercapai atau belum. Maka dalam rangka evaluasi, siswa selalu dituntut untuk memberikan prestasi-prestasi tertentu yang akan menampakkan 
hasil belajar secara nyata dan yang relevan bagi tujuan instruksional. Dari tepat atau tidak tepatnya prestasi belajar, dapat ditarik kesimpulan mengenai kemampuan internal individu.

Keberhasilan dalam studi merupakan suatu hal yang sangat diharapkan baik oleh individu, orang tua maupun institusi dimana individu itu berada. Keberhasilan tersebut tentunya didu-kung oleh berbagai faktor baik internal mau-pun eksternal. Salah satu faktor personal yang secara umum diduga berpengaruh pada kebe-rhasilan studi adalah faktor kecerdasan inte-lektual (Miron, 2004 dalam Hikmawati, 2009). Menurut Wechsler (1944: 3) kecerdasan inte-lektual adalah suatu agregat atau kapasitas global dari individu untuk dapat bertindak secara rasional dan berhubungan secara efektif dengan lingkungannya. Mahasiswa yang cerdas secara intelektual diduga mampu manjalani proses perkuliahan serta mengerjakan semua tugas yang diberikan kepadanya secara logis, efektif dan efisien. Proses belajar yang logis, efektif dan efisien ini diduga mampu membantu mahasiswa dalam memperoleh prestasi yang maksimal.

Hasil penelitian Hikmawati, dkk (2009) menunjukkan bahwa kecerdasan intelektual memiliki pengaruh yang cukup signifikan terhadap prestasi belajar. Hal tersebut terjadi karena menurutnya kecerdasan intelektual memiliki pengaruh yang signifikan terhadap kecepatan dan efektivitas mahasiswa dalam memroses bahan ajar yang diberikan kepadanya. Mahasiswa yang mempunyai taraf kecerdasan yang rendah akan mengalami kesulitan di dalam menangkap, memahami, dan menyimpan informasi yang disampaikan oleh dosennya. Bukan hanya itu, ia pun diduga akan kesulitan di dalam menganalisis, membayangkan, dan melakukan penilaian secara logis dan akurat sehingga secara tidak langsung prestasi belajar yang diperolehnya tidak akan maksimal.

Faktor lain yang diduga mempunyai peran terhadap diperolehnya prestasi belajar yang maksimal adalah adanya keteraturan diri dalam belajar (self regulated learning). Menurut Zimmerman (2001:1) keteraturan diri dalam belajar (self regulated learning) adalah usaha yang sistematis untuk mengarahkan pikiran, perasaan dan tindakan untuk mencapai tujuan yang dimiliki. Berdasarkan tiga tahapan keteraturan diri dalam belajar (self regulated learning) yang dikemukakan oleh Zimmerman \& Kitsantas (2005:514) diperoleh analisa sebagai berikut:
Pada fase persiapan (forethought phase), individu mempersiapkan diri untuk menentukan hal-hal yang dibutuhkan dalam proses belajarnya. Pada fase ini mahasiswa yang mempunyai keteraturan dalam belajar (self regulated learning) yang tinggi, ketika mereka akan menghadapi suatu mata kuliah mereka terlebih dahulu menentukan tujuan yang ingin mereka capai dari mata kuliah yang dihadapinya, merencanakan strategi belajar yang akan digunakan, kemudian memiliki keyakinan akan manfaat atau keuntungan yang akan didapatkan dari proses belajar yang dilakukannya, berusaha menyenangi pelajaran yang dihadapi, dan belajar dengan berorientasi untuk mengembangkan kemampuan.

Sebaliknya, mahasiswa yang mempunyai keteraturan diri dalam belajar (self regulated learning) yang rendah, ketika mereka akan menghadapi suatu mata kuliah mereka tidak terlebih dahulu menentukan tujuan yang ingin mereka capai dari pelajaran yang dihadapinya, tidak atau kurang merencanakan strategi belajar yang akan digunakan, kemudian tidak atau kurang memiliki keyakinan akan manfaat atau keuntungan yang akan didapatkan dari proses belajar yang dilakukannya, tidak atau kurang berusaha menyenangi pelajaran yang dihadapi, dan belajar dengan berorientasi untuk mendapatkan kesuksesan

Pada fase pelaksanaan (performance phase), individu mengatur dan mengontrol konsentrasi atau performa dalam proses belajarnya. Mahasiswa yang mempunyai keteraturan dalam belajar (self regulated learning) yang tinggi, pada fase ini mereka berusaha menggunakan strategi dalam membantu proses belajarnya, yaitu dengan menggunakan self instruction, imagery, menjaga fokus perhatian, melakukan manajemen waktu, mencari bantuan apabila mengalami kesulitan atau mendapatkan hambatan dalam proses belajarnya, dan menciptakan lingkungan yang kondusif bagi mereka untuk belajar. Selain itu, mereka juga memperhatikan aspek-aspek atau kondisikondisi yang dapat memengaruhi hasil belajar yang mereka peroleh, serta memperhatikan usaha-usaha pemecahan masalah yang pernah dilakukan sebelumnya dan menjadikannya sebagai informasi dalam aktivitas belajar selanjutnya.

Sebaliknya, pada mahasiswa yang mempunyai keteraturan dalam belajar (self regulated learning) yang rendah, yaitu mereka ti- 
dak menggunakan strategi dalam proses belajarnya, kurang memperhatikan aspek-aspek atau kondisi-kondisi yang dapat memengaruhi hasil belajar yang mereka peroleh, serta kurang memperhatikan usaha-usaha pemecahan masalah yang dilakukan sebelumnya dan menjadikannya sebagai informasi dalam aktivitas belajar selanjutnya.

Pada fase refleksi diri (self reflection phase), individu memaknai pengalaman belajarnya atau melakukan refleksi atas apa yang telah dilakukannya. Pada fase ini mahasiswa yang mempunyai keteraturan diri dalam belajar (self regulated learning) yang tinggi, mereka melakukan evaluasi diri berkaitan dengan aktivitas belajar yang dilakukannya, mengatribusikan kegagalan dan kesuksesannya dalam belajar sebagai sesuatu yang dapat dikendalikan, kepuasan atau ketidakpuasan terhadap hasil belajar yang mereka peroleh membuat mereka lebih tekun dan lebih dapat mengarahkan usaha belajarnya, dan juga mereka bersikap adaftif terhadap tuntutan perubahan dalam aktivitas belajarnya.

Sebaliknya, mahasiswa yang mempunyai keteraturan diri dalam belajar (self regulated learning) yang rendah, mereka kurang melakukan evaluasi diri berkaitan dengan aktivitas belajar yang dilakukannya, mengatribusikan kegagalan dan kesuksesannya dalam belajar sebagai sesuatu yang tidak dapat dikendalikan, kepuasan atau ketidakpuasan terhadap hasil belajar yang mereka peroleh membuat putus asa, dan juga mereka bersikap depensif terhadap tuntutan perubahan dalam aktivitas belajarnya.

Berbagai fase yang dilewati oleh mahasiswa yang memiliki keteraturan diri dalam belajar (self regulated learning) yang tinggi diasumsikan dapat menghasilkan prestasi belajar yang tinggi. Sebaliknya mahasiswa yang memiliki keteraturan diri dalam belajar (self regulated learning) yang rendah diasumsikan dapat menghasilkan prestasi belajar yang rendah juga.

\section{METODE PENELITIAN}

Rancangan penelitian ini termasuk penelitian korelasional, multiple regression. Yaitu cara lain untuk menggambarkan dan mengevaluasi hubungan antara beberapa variabel dengan asumsi bahwa satu variabel berperan sebagai criterion variable, dan beberapa variabel berperan sebagai predictor variable (Clark-Carter, 2004 dalam Hikmawati, dkk, 2009). Dengan multiple regression dimungkinkan untuk meramalkan suatu variabel berdasarkan nilai dari beberapa prediktor. Asumsinya dengan menggunakan beberapa prediktor akan membuat prediksi menjadi lebih akurat. Selain itu, dengan multiple regression dimungkinkan secara statistik mengukur pengaruh beberapa variabel prediktor dengan mengendalikan variabel prediktor lain (Blaikie, 2003 dalam Hikmawati, dkk, 2009). Dalam penelitian ini, terdapat 2 prediktor yang dipandang dapat mempengaruhi prestasi belajar yaitu: tingkat kecerdasan intelektual dan tingkat keteraturan diri dalam belajar (self regulated learning).

Menurut Wechsler (1944: 3) kecerdasan intelektual adalah suatu agregat atau kapasitas global dari individu untuk dapat bertindak secara rasional dan berhubungan secara efektif dengan lingkungannya.

Secara operasional, taraf kecerdasan intelektual yang dimaksud dalam penelitian ini dilihat dari total skor kecerdasan pada tes IQ (dengan menggunakan IST/Intelligenz Struktur Test) Mahasiswa Psikologi UIN Sunan Gunung Djati Bandung. Jika total skor subjek pada IST kurang dari 90, maka subjek mempunyai taraf kecerdasan di bawah rata-rata kemudian diberi kode 1; jika total skor subjek pada IST berada pada kisaran 90 sampai dengan 110, maka subjek mempunyai taraf kecerdasan rata-rata dan diberi kode 2; dan jika total skor subjek pada IST lebih dari 110 maka subjek mempunyai taraf kecerdasan di atas rata-rata dan diberi kode 3 .

Berdasarkan konsep dari Zimmerman (2000, dalam Schunk, 2001:1) keteraturan diri dalam belajar (self regulated learning) adalah usaha yang sistematis untuk mengarahkan pikiran, perasaan dan tindakan untuk mencapai tujuan yang dimiliki. Dalam hal ini melibatkan 3 fase, yaitu Forethought Phase, Performance Phase, dan Self Reflection Phase.

Secara operasional, keteraturan diri dalam belajar (Self Regulated Learning) pada penelitian ini diukur dari bagaimana fase-fase dan proses yang terlibat dalam keteraturan diri dalam belajar (self regulated learning) dilakukan oleh Mahasiswa Psikologi UIN Sunan Gunung Djati Bandung, dan untuk melihat hal tersebut diungkap melalui Skala Keteraturan Diri dalam Belajar (Self Regulated Learning). 
Oleh karena itu, yang dimaksud keteraturan diri dalam belajar (self regulated learning) pada penelitian ini adalah skor total skala Keteraturan Diri dalam Belajar (Self Regulated Learning). Dalam hal ini, tinggi rendahnya skor menunjukan tingkat keteraturan diri dalam belajar yang dimiliki oleh Mahasiswa Psikologi UIN Sunan Gunung Djati Bandung angkatan 2007.

Prestasi belajar menurut Good (1973; dalam Gage, N. L. \& Berliner, D. C. 1979) adalah pengetahuan yang diperoleh atau keterampilan yang dikembangkan dalam mata pelajaran di sekolah yang biasanya diperoleh melalui skor tes atau nilai yang diberikan oleh pengajar. Secara operasional prestasi belajar yang dimaksud dalam penelitian ini adalah pengetahuan dan keterampilan yang dimiliki mahasiswa yang dibuktikan dalam bentuk nilai indeks prestasi kumulatif (IPK).

Instrumen yang digunakan untuk menjaring data mengenai tingkat kecerdasan intelektual diperoleh dari hasil psikotes yang diselenggarakan oleh Laboratorium Fakultas Psikologi UIN SGD Bandung, instrument yang menjaring data mengenai keteraturan diri dalam belajar (self regulated learning) berbentuk kuesioner dengan skala Likert. Sedangkan instrumen yang digunakan untuk menjaring data mengenai prestasi belajar adalah bukti tertulis nilai mahasiswa dalam bentuk nilai indeks prestasi kumulatif (IPK) yang diperoleh dari bagian akademik Fakultas Psikologi UIN Sunan Gunung Djati Bandung.

Metode analisis data yang digunakan untuk menguji hipotesis dalam penelitian ini adalah analisis regresi, karena penelitian ini mengungkap dua prediktor dan satu kriterium.

\section{HASIL DAN PEMBAHASAN}

\section{Hasil}

Berdasarkan hasil perhitungan diketahui bahwa nilai $\mathrm{F}$ sebesar 37.095 dengan $\mathrm{P}$ value lebih kecil dari nilai alpha 0.05 . Hal tersebut menunjukkan bahwa hipotesis nol (Ho) ditolak dan hipotesis alternatif $\left(\mathrm{H}_{1}\right)$ diterima. Artinya bahwa kecerdasan intelektual dan keteraturan diri dalam belajar (self regulated learning) secara bersama-sama berpengaruh secara signifikan terhadap prestasi belajar.
Hasil perhitungan menunjukkan bahwa koefisien korelasi kedua variabel independen dengan variabel dependen sebesar 0.564 dengan nilai $\mathrm{R}^{2}$ sebesar 0.318 . Hal tersebut menunjukkan bahwa variasi pada prestasi belajar $31 \%$ ditentukan oleh kecerdasan intelektual dan keteraturan diri dalam belajar (self regulated learning). Sementara itu, $69 \%$ lagi ditentukan oleh variabel lain.

Selain itu diketahui bahwa koefisien regresi dari kecerdasan intelektual adalah sebesar 0.530. Hasil tersebut sangat signifikan karena nilai $\mathrm{P}$ value lebih kecil dari $\alpha$ yaitu $0.000<0.05$. Hal tersebut memiliki arti bahwa kecerdasan intelektual secara signifikan berpengaruh terhadap prestasi belajar.

Hasil perhitungan berikutnya menunjukkan bahwa koefisien regresi dari keteraturan diri dalam belajar (self regulated learning) adalah sebesar 0.261. Hasil tersebut sangat signifikan karena nilai $\mathrm{P}$ value lebih kecil dari $\alpha$ yaitu $0.001<0.05$. Hal tersebut memiliki arti bahwa keteraturan diri dalam belajar (self regulated learning) secara signifikan berpengaruh terhadap prestasi belajar.

\section{Pembahasan}

Hasil pengujian hipotesis menunjukkan bahwa kecerdasan intelektual dan keteraturan diri dalam belajar (self regulated learning) secara bersama-sama memberikan pengaruh yang signifikan terhadap prestasi belajar. Berdasarkan hasil analisis regresi dengan metode enter, diperoleh hasil koefisien korelasi Freg = $37,095 \mathrm{p}<0,000$ dengan koefisien determinasi $\left(\mathrm{R}^{2}\right)$ sebesar 0,31 atau $31 \%$. Berdasarkan hasil perhitungan analisis regresi tersebut maka hipotesis yang diajukan dalam penelitian ini dapat diterima yaitu terdapat pengaruh yang signifikan dari kecerdasan intelektual dan keteraturan diri dalam belajar (self regulated learning) terhadap prestasi belajar.

Hasil kategorisasi menunjukkan bahwa sebagian besar mahasiswa yang memiliki tingkat kecerdasan intelektual yang tinggi memiliki prestasi yang tinggi, demikian pula sebaliknya. Hal tersebut memiliki arti bahwa tingkat kecerdasan intelektual memiliki pengaruh terhadap prestasi belajar. Hasil penelitian tersebut diperkuat dengan penelitian yang dilakukan oleh Hikmawati, dkk (2009) yang menunjukkan bahwa kecerdasan intelektual memiliki 
pengaruh yang cukup signifikan terhadap prestasi belajar. Hal tersebut terjadi karena menurutnya kecerdasan intelektual berpengaruh terhadap kecepatan dan efektivitas penerimaan, pengolahan, penilaian, serta penyimpanan bahan ajar.

Tingkat kecerdasan intelegensi yang dimiliki mahasiswa memiliki pengaruh terhadap prestasi belajar, karena mahasiswa yang mempunyai taraf kecerdasan yang tinggi akan memiliki kelebihan di dalam menangkap, memahami, dan menyimpan informasi yang disampaikan oleh dosennya. Bukan hanya itu, ia pun akan memiliki kemampuan yang baik di dalam menganalisis, membayangkan, dan melakukan penilaian secara logis dan akurat sehingga secara tidak langsung prestasi belajar yang diperolehnya akan maksimal.

Hasil penelitian ini juga memperkuat pendapat Naylor (1972; dalam Elma Amalia 2002: 48) yang mengungkapkan bahwa prestasi belajar yang dicapai seorang siswa erat kaitannya dengan tingkat inteligensi yang dimilikinya. Siswa yang memiliki tingkat intelegensi tinggi akan lebih mudah untuk menangkap, mencerna, dan memahami materi pelajaran yang diterimanya dibandingkan dengan anak yang tingkat inteligensinya rendah.

Hasil kategorisasi lain menunjukkan bahwa sebagian besar mahasiswa yang memiliki tingkat keteraturan diri dalam belajar (self regulated learning) yang tinggi memiliki tingkat prestasi belajar yang tinggi pula. Hal tersebut memiliki arti bahwa tingkat keteraturan diri dalam belajar (self regulated learning) juga memiliki pengaruh terhadap prestasi belajar. Hasil penelitian tersebut, memperkuat pendapat Naylor (1972; dalam Elma Amalia 2002: 49) yang mengungkapkan bahwa siswa yang berprestasi tinggi lebih realistik dalam memilih tujuannya daripada siswa yang berprestasi rendah. Mahasiswa yang realistis mampu melakukan persiapan dalam proses belajar, melaksanakan aktivitas belajar dengan maksimal serta mampu melakukan evaluasi pribadi terhadap berbagai kelebihan, kekurangan hambatan serta peluang yang dimilikinya. Menurut Zimmerman (2002: 39-41, 64), berbagai kegiatan yang dilakukan oleh individu tersebut dinamakan dengan keteraturan diri dalam belajar (self regulated learning).

Berdasarkan konsep yang dikemukakan oleh Zimmerman (2002), hasil penelitian menunjukkan bahwa pada fase persiapan (fore- thought phase), mahasiswa yang mempunyai keteraturan dalam belajar (self regulated learning) yang tinggi, ketika akan menghadapi suatu mata kuliah terlebih dahulu menentukan tujuan yang ingin mereka capai dari mata kuliah yang dihadapinya, merencanakan strategi belajar yang akan digunakan, kemudian memiliki keyakinan akan manfaat atau keuntungan yang didapatkan dari proses belajar yang dilakukannya, berusaha menyenangi pelajaran yang dihadapi, dan belajar dengan berorientasi untuk mengembangkan kemampuan.

Pada fase pelaksanaan (performance phase), mahasiswa yang mempunyai keteraturan dalam belajar (self regulated learning) yang tinggi sudah berusaha menggunakan strategi dalam membantu proses belajarnya, yaitu dengan menggunakan self instruction, imagery, menjaga fokus perhatian, melakukan manajemen waktu, mencari bantuan apabila mengalami kesulitan atau mendapatkan hambatan dalam proses belajarnya, dan menciptakan lingkungan yang kondusif untuk belajar. Selain itu, mereka juga memperhatikan aspekaspek atau kondisi-kondisi yang dapat memengaruhi hasil belajar yang diperoleh, serta memperhatikan usaha-usaha pemecahan masalah yang pernah dilakukan sebelumnya dan menjadikannya sebagai informasi dalam aktivitas belajar selanjutnya.

Pada fase refleksi diri (self reflection phase), mahasiswa yang mempunyai keteraturan diri dalam belajar (self regulated learning) yang tinggi, sudah melakukan evaluasi diri berkaitan dengan aktivitas belajar yang dilakukannya, mengatribusikan kegagalan dan kesuksesannya dalam belajar sebagai sesuatu yang dapat dikendalikan, kepuasan atau ketidakpuasan terhadap hasil belajar yang diperoleh membuat mereka lebih tekun dan lebih dapat mengarahkan usaha belajarnya, dan juga bersikap adaftif terhadap tuntutan perubahan dalam aktivitas belajarnya.

Berbagai fase yang dilewati oleh mahasiswa yang memiliki keteraturan diri dalam belajar (self regulated learning) yang tinggi sudah terbukti secara signifikan menghasilkan prestasi belajar yang tinggi. Sebaliknya mahasiswa yang memiliki keteraturan diri dalam belajar (self regulated learning) rendah terbukti memiliki prestasi belajar yang rendah juga.

Terdapat hal menarik dari data deskriptif yang dijelaskan sebelumnya, yaitu terdapat sebagian (9\%) mahasiswa yang memiliki tingkat 
kecerdasan intelektual yang tinggi namun memiliki prestasi belajar yang rendah. Begitu pula sebagian (23\%) siswa lainnya yang memiliki tingkat kecerdasan intelektual yang rendah namun memiliki prestasi belajar yang tinggi.

Apabila dilihat dari data yang dimiliki oleh peneliti, hal tersebut terjadi karena adanya mahasiswa yang memiliki tingkat kecerdasan intelektual yang tinggi namun memiliki keteraturan diri dalam belajar (self regulated learning) yang rendah. Begitu pula sebaliknya ada mahasiswa yang memiliki tingkat kecerdasan intelektual yang rendah namun memiliki keteraturan diri dalam belajar (self regulated learning) yang tinggi.

Menurut Zimmerman (1989:2-7) hal tersebut terjadi karena keteraturan diri dalam belajar (self regulated learning) bukan hanya dipengaruhi oleh faktor intelegensi saja, tetapi oleh faktor lainnya, yaitu individu yang bersangkutan (person), faktor tingkah laku (behavior), dan faktor lingkungan (environment). Yang termasuk ke dalam faktor personal ialah pengetahuan siswa (student knowledge), proses metakognitif (metacognitive process) tujuan (goals) serta afek (affect) yang dimilikinya. Yang termasuk ke dalam faktor tingkah laku ialah pengamatan diri (self observation), penilaian diri (self judgment) serta reaksi diri (self reaction). Sedangkan yang termasuk ke dalam faktor lingkungan ialah: pemodelan (modeling) dan bujukan verbal (verbal persuasion).

Hal lain yang menarik bagi peneliti adalah terdapat sebagian (18\%) mahasiswa yang memiliki tingkat keteraturan diri dalam belajar (self regulated learning) yang rendah namun memiliki prestasi belajar yang tinggi. Begitu pula sebagian (24\%) siswa yang memiliki tingkat keteraturan diri dalam belajar (self regulated learning) yang tinggi namun memiliki prestasi belajar yang rendah.

Apabila dilihat dari data yang dimiliki oleh peneliti, hal tersebut terjadi karena adanya mahasiswa yang memiliki keteraturan diri dalam belajar (self regulated learning) yang rendah namun memiliki tingkat kecerdasan intelektual yang tinggi. Begitu pula sebaliknya ada mahasiswa yang memiliki tingkat keteraturan diri dalam belajar (self regulated learning) yang tinggi namun memiliki kecerdasan intelektual yang rendah. Berdasarkan hasil analisis, terdapat beberapa kasus yang cukup menarik bagi peneliti, yaitu terdapat beberapa (4\%) mahasiswa yang memiliki kecerdasan intelektual serta tingkat keteraturan diri dalam belajar (self regulated learning) yang rendah namun memiliki prestasi belajar yang tinggi. Begitu pula sebaliknya, terdapat beberapa (8\%) mahasiswa yang memiliki kecerdasan intelektual serta tingkat keteraturan diri dalam belajar (self regulated learning) yang tinggi namun memiliki prestasi belajar yang rendah. Berdasarkan hasil analisis data, hal tersebut terjadi karena kecerdasan intelektual serta keteraturan diri dalam belajar (self regulated learning) hanya menentukan $31 \%$ variasi skor pada prestasi belajar, sedangkan 69\% sisanya ditentukan oleh variabel lain yang masih harus diselidiki oleh peneliti lain.

\section{SIMPULAN DAN SARAN}

\section{Simpulan}

Berdasarkan hasil analisis dan pembahasan tentang peran kecerdasan intelektual dan keteraturan diri dalam belajar (self regulated learning) terhadap prestasi belajar mahasiswa Fakultas Psikologi UIN Sunan Gunung Djati Bandung dapat ditarik simpulan sebagai berikut:

Sebagian besar mahasiswa Fakultas Psikologi UIN Sunan Gunung Djati Bandung angkatan 2007-2008 memiliki tingkat kecerdasan pada tingkat rata-rata, sisanya berada di bawah rata-rata serta hanya sebagian kecil mahasiswa yang memiliki tingkat kecerdasan intelektual di atas rata-rata.

Tidak terdapat perbedaan yang signifikan perbandingan jumlah mahasiswa yang memiliki tingkat keteraturan diri dalam belajar (self regulated learning) yang tinggi dengan jumlah mahasiswa yang memiliki tingkat keteraturan diri dalam belajar (self regulated learning) yang rendah.

Berdasarkan hasil analisis diketahui bahwa kecerdasan intelektual dan keteraturan diri dalam belajar (self regulated learning) secara bersama-sama berpengaruh secara signifikan terhadap prestasi belajar,

Hasil analisis juga menunjukkan bahwa variabel kecerdasan intelektual memiliki pengaruh yang lebih besar bila dibandingkan dengan variabel keteraturan diri dalam belajar (self regulated learning). 


\section{Saran}

Berdasarkan hasil penelitian yang telah dilakukan, dengan memperhatikan keterbatasan-keterbatasan dalam penelitian ini, peneliti mengajukan saran-saran agar dapat dijadikan bahan pertimbangan sebagai berikut:

Bagi fakultas, dikarenakan hasil penelitian menunjukkan bahwa taraf kecerdasan merupakan prediktor yang signifikan berpengaruh terhadap tinggi-rendahnya prestasi belajar mahasiswa Fakultas Psikologi UIN SGD Bandung. Oleh karena itu, dalam proses penerimaan mahasiswa khususnya Fakultas Psikologi UIN SGD Bandung selain melalui PPA, ujian lokal, atau SPMB/SMPTN juga sebaiknya dilakukan pengukuran kecerdasan (tes IQ), baik taraf maupun struktur kecerdasannya.

Saran lain yang diajukan bagi fakultas adalah, karena pada kenyataanya ada beberapa mahasiswa yang memiliki kecerdasan intelektual yang tinggi tetapi memperoleh prestasi yang rendah, maka diharapkan fakultas mengadakan kegiatan yang membangun mahasiswa untuk belajar lebih efektif, misalnya melalui training keteraturan diri dalam belajar, training motivasi atau kegiatan lain yang bermanfaat supaya potensi yang dimilikinya dapat dioptimalkan.

Bagi pembimbing akademik, dalam proses bimbingan diharapkan dapat memberikan arahan kepada mahasiswa mengenai pentingnya keteraturan diri dalam belajar (self regulated learning). Karena keteraturan diri dalam belajar (self regulated learning) merupakan suatu bentuk persiapan dan strategi yang bisa mereka gunakan agar dapat merealisasikan orientasi pendidikannya di masa depan.

Untuk penelitian selanjutnya, karena pada penelitian ini masih terdapat kasus yang cukup menarik dan perlu dijawab serta diteliti kembali yaitu terdapat mahasiswa yang memiliki kecerdasan intelektual serta tingkat keteraturan diri dalam belajar yang tinggi namun memiliki prestasi belajar yang rendah, begitu pula sebaliknya terdapat mahasiswa yang memiliki kecerdasan intelektual serta tingkat keteraturan diri dalam belajar yang rendah namun memiliki prestasi belajar yang tinggi. Berdasarkan hasil analisis, hal tersebut mungkin saja terjadi karena kecerdasan intelektual serta keteraturan diri dalam belajar hanya menentukan $31 \%$ tingkat prestasi belajar, sedangkan $69 \%$ persen lainnya ditentukan va- riabel lainnya. Karenanya, peneliti memberi masukkan kepada peneliti lain untuk mencari variabel lain yang diduga memiliki pengaruh yang lebih signifikan.

\section{DAFTAR PUSTAKA}

Arikunto, Suharsimi. 2000. Manajemen Penelitian. Jakarta: Rineka Cipta.

Azwar, Saefuddin. 2004. Penyusunan Skala Psikologi. Yogyakarta: Pustaka Pelajar Offset.

1996. Psikologi Intelegensi. Yogyakarta: Pustaka Pelajar.

Ashshiddiqi, Hasbi. dkk. 1971. Al-Qur'an dan Terjemahannya. : Jakarta.

Elma, A. 2002. Hubungan antara Self Esteem dan Prestasi Akademis. Skripsi Fakultas Psikologi UNPAD Bandung: (tidak diterbitkan)

Friedenberg, Lisa. 1995. Psychological Testing Design Analysis and Use. Massachusetts: Allyn\&Bacon.

Guillford. J.P. 1959. Fundamental Statistic in Psychology and Education. New York: Mc Graw Hill Book Company

Hadi, Sutrisno. 2001. Metodologi Research. Andi : Yogyakarta.

Hasyimi, Ahmad. 2001. Muhtarul Ahadits Annabawiyyah Wal Hikamul Muhammadiyah. Libanon: Darl Fikr.

Hikmawati, F., dkk. 2009. Prediktor Keberhasilan Studi pada Mahasiswa di Fakultas Psikologi Uin Sunan Gunung Djati Bandung. Skripsi UIN Sunan Gunung Djati Bandung: (tidak diterbitkan)

Lapan, Richard T., Kardas, Carol Anne M.\& Turner, Sherri. 2002. Empowering Student to Become Self Regulated Learners.

Najati, Usman Muhammad. 2003. Psikologi dalam Tinjauan Hadits Nabi SAW. Jakarta: Mustaqiim.

Nasir, H. Sahilun. 1999. Peran Pendidikan Agama Terhadap Pemecahan Problema Remaja. Kalam Mulia : Jakarta.

Nurafifah, F. 2007. Hubungan Antara Orientasi Masa Depan dalam Bidang Pendidikan Dengan Keteraturan Diri dalam Belajar (Self Regulated Learning) Pada Siswa-siswi Kelas XII SMA Karya Budi Cileunyi Bandung. Bandung: (tidak diterbitkan)

Purwanto, N 1990. Psikologi Pendidikan. Bandung: Remaja Rosda Karya. 
Ruohotie, Pekka. 2002. Motivation and Self Regulation in Learning. In H.Niemi.\& P.Ruohotie (Eds), Theoretical Understanding for Learning in the Virtual University (pp.37-70). Hameenlinna: Finland:RCVE. http://www.uta.Fi.

Schunk, Dale H. 2001. Self Regulation through Goal Setting. http://www.tourettesyndrome. net.

Sears, David O.,Freedman, Jonathan. Peplau.L, Anne. 1994. Psikologi Sosial (Terj). Jakarta: Penerbit Erlangga.

Siegel, Sidney. 1997. Statistik Nonparametrik Untuk Ilmu-Ilmu Sosial (terj). Jakarta: Gramedia Pustaka Utama.

Sudjana. 1996. Metoda Statistika edisi keenam. Bandung: Tarsito

Sugiyono. \& Wibowo, Eri. 2001. Statistika penelitian. Bandung: Alfabeta

Suryabrata, S. 1990. Psikologi Pendidikan. Jakarta: Rajawali Press.

Suwaidi, Muhammad Nur. 1992. Manhaj AtTarbiyah An-Nabawiyyah Lithifl. Kwait:
Maktabah Al Manaar Al Islamiyah.

Wechsler, D. 1944. The Measurement Of Adult Intellegence. New York: The William \& Wilkins Company.

Winkel, WS. 1995. Psikologi Pengajaran. Jakarta: Rineka Cipta.

Woolfolk, Anita E. 1993. Educational Psychology Fifth Edition. USA: Allyn and Bacon.

Zimmerman, Barry.J. \& Risembereg, Rafael. 2007. Self Regulatory Dimensions of Academic Learning and Motivation. New York: Academic Press, Inc

Zimmerman, Barry.J. \& Kitsantas, Anastasia. 2005. The Hidden Dimension of Personal Competence: Self Regulated Learning and Practice. In Elliot, Andrew J. \& Dweck, Carol S. 2005. Handbook of Competence and Motivation. New York: The Guilford Press.

Zimmerman, Barry.J. 1989. A Social Cognitive Of Self Regulated Academic Learning. Journal of Educational Psychology. 